markedly better on the physical or colloid chemical side, where work is being done arising largely out of Service requirements, although some of it is rather long-term in nature. In 'pure' biochemistry it might be argued that there are very few real war problems at all, and this has led to quite a few research workers either continuing with academic research or taking up what might aptly be called a 'pseudo' war problem. It is necessary for biochemists to branch out into the related and more immediately useful fields of nutrition, medicine, bacteriology, agriculture and industrial fermentation. Difficulties here are the sketchy organization of biochemists for war purposes and the generally unco-operative attitude of industry.

The difficulty of meeting or corresponding with colleagues engaged on the same or similar work was instanced by speakers from various laboratories. The official attitude is often one of discouragement or even surprise, and many workers seem to have to rely on chance personal contacts. The stringency of secrecy regulations is sometimes too great, and has the undesirable effect of hampering the progress of work by preventing discussion with other scientific workers attacking similar problems. It is often particularly difficult for university men to obtain the necessary collaboration with industry or with Government laboratories.

The position of Ph.D. students was touched on by several contributors to the discussion. It is necessary to decide whether such persons are students being trained in some specialized branch of science, or whether they should be regarded as scientific workers of adequate experience to carry out successfully certain specific pieces of war work. The general opinion favoured the latter course as being more in line with the urgent needs of the situation, but it was felt that a modification of the University regula. tions to meet this point is necessary. Provision for students to submit secret war work in a dissertation for a higher degree has been made with apparent success in other universities, notably Oxford. Apart from secrecy precautions, there are difficulties in assessing a student's work if he has been working in a research team or has been engaged on a number of small isolated problems.

The crux of the matter was brought out by one speaker who gave a definition of war research. Scientific work can only be considered as war work when it is very probable that it will give results which can be applied to this War. Any other form of research is either 'pseudo' war work, or not war work at all. In particular, the urgent need for technical advance in the present eritical war situation must be realized. Probably the prime need is for individuals to appreciate their responsibilities to the nation, and themselves actively set about obtaining definite war problems. Difficulties, often considerable, do exist, but they must be expected and overcome. Many university scientific workers need to change their outlook and stop looking for a major research project in short-term pieces of work. Much of the difficulty arises because academic scientific workers are tempted too much to pick and choose their subjects for research. The essential thing now is the usefulness of the research, not its inherent scientific interest. They should be prepared to change over to completely new fields if there is little of direct application in their own, or even to take up work of a more routine nature. A man called up into the Forces has to learn a completely new art, so why not the man of science, who after all is in a sheltered position in the War?

While the meeting emphasized the need for personal initiative and hard work on the part of the individual man of science, it was clearly in no doubt that the setting up of a national body with executive power to plan scientific work is long overdue. A resolution, which was unanimously carried, gave expression to this opinion by supporting whole. heartedly the demands for a Joint Technical Board or Technical Planning Committee "with executive authority to co-ordinate research, design and development", and pointed out the necessity for such a body having the closest contacts with rank-and-file scientific workers. The maximum effort of Cambridge men of science to help the war effort was promised, and it was urged that, subject to necessary conditions of secrecy, all scientific workers engaged on similar problems or employed in the same place shall meet regularly to discuss progress and plan future advance.

\section{COBALT-NICKEL DEPOSITION}

A $\mathrm{N}$ article in the Electrical Review of July 3 by A c. C. Downio describes the developments which have taken place in the last three years on research into the deposition of cobalt-nickel alloy. This alloy is at least three times as hard as nickel itself, and is more resistant to corrosion than either cobalt or nickel alone. Moreover, the process is within the bright plating eategory which obviates the need for subsequent buffing or polishing. The nickel used is electro-refined wire or strip and is even purer than the product obtainable from the carbonyl process. The best metallic cobalt to use is that obtained by special reduction of the oxide, such as by the Kalmus process, which is completely free from carbon and practically all other solid impurities. For all smaller work it suffices to use nickel and cobalt inter-wound in the form of wire or strip, to present a uniform surface closely akin to a solid anode.

Nickel is analysed by the dimethylglyoxime method and cobalt by the nitroso- $\beta$-naphthol method. For initial experiments the cathode may be of platinum sheet, so that all features of the deposition at different current densities and concentrations of the two metals can be followed, before commencing operations. The deposits can be made very ductile, so as to bend or twist without any tendency to lift or peel, while what is known as 'double-plate' is rarely encountered.

Earlier work done by Fink and Lah proved the wide range of silver-white deposits which could be obtained from different cobalt nickel compositions, which in combined chloride-sulphate baths can contain 55-75 per cent of nickel with 45-25 per cent of cobalt. Afterwards, Young and Gould found that the mixed bath can provide almost any desired com. position of deposit at a current density of from 10 to $30 \mathrm{amp}$./sq. ft., with or without agitation. Researches by Brockman and Nowlen showed that the density can be increased to between 32 and $144 \mathrm{amp} . / \mathrm{sq}$. ft. with a different type of electrolyte. Advantage has been taken of a similar composition for the dual deposition in a bath consisting (in oz./gal.) of $26 \cdot 1$ nickel sulphate crystals, $4 \cdot 7$ cobalt sulphate crystals, 2 sodium chloride, and $3 \cdot 25$ boric acid, maintained 
at $20^{\circ}$ at a $p H$ value of $5 \cdot 5-5 \cdot 8$ at a maximum of $30 \mathrm{amp} . / \mathrm{sq}$. $\mathrm{ft}$.

This composition gives eppreciable control of the two metals, for if the temperature of the bath be increased the proportion of cobalt will be increased with a corresponding diminution of the nickel. Alternatively, by increasing the speed of rotation of the cathode, the nickel proportion can again be decreased. To reduce the cobalt proportion the current density only need be suitably decreased, while by lowering the $p H$ towards acidity the alloy deposited acquires directly an increased nickel content at the expense of the cobalt. The introduction of triethanolamine makes it possible to deposit almost any proportions of cobalt and nickel.

The composition of such alkaline baths (in oz./gal.) is 10.7 nickel sulphate crystals, 4 nickel chloride crystals, 4 anhydrous sodium sulphate, and 16 triethanolamine, together with a second solution composed of $10 \cdot 7$ cobalt sulphate crystals, and 13.5 triethanolamine. In the latter instance the temperature of the bath is maintained at $23^{\circ} \mathrm{C}$. and the two solutions are added in measured proportions as required. The corrosion-resisting properties of the combined cobalt-nickel deposit by far exceed those of the constituent metals, while the range of hardness, ductility and toughness is still further increased. The last two mentioned qualities are of special importance in the plating of stereotypes, where brightness is of no great account. The printing surface must withstand wear for lengthy periods without deteriorating, in which respect cobalt-nickel deposit has been of great practical value. The same type of deposit has been applied to the manufacture of rayon and other artificial silks, to surfaces which are exposed to heavy wear in regular textile mills and in modern laundry practice. In various instruments, automatic machines, and the finer parts of acoustic devices, cobalt-nickel deposit is preferred on account of the wide range of physical properties available.

\section{APPOINTMENTS VACANT}

APPLICATIONs are invited for the following appointments on or before the dates mentioned :

Assistant ChEMist (MALE oR FEMALE)-The Clerk and Manager, West Midlands Joint Electricity Authority, Phœnix Buildings, Dudley Road, Wolverhampton (endorsed 'Assistant Chemist') (August 14).

Lecturer in Engineering at the Walker Technical College, Oakengates-The Secretary for Education, Education Office, County Buildings, Shrewsbury (August 15).

GRADUATE LECTORER IN BIOLOGY at the Crumlin Mining and Technical College-The Director of Education, Higher Education Department, County Hall, Newport, Mon. (August 15).

ENGINEER AND SECRETART TO THE ISLe OF MAN ElectrictTy BOARD-The Chairman of the Isle of Man Electricity Board, Electric House, Circular Road, Douglas, Isle of Man (endorsed 'Appointment of Engineer and Secretary') (August 17).

Gradtate Lecturers in Mechanical and Electrical EngineherING at the Lincoln Technical College-The Director of Education, ING at the Lincoln Technical College-The Director of Ed

Assistany to the Chief Research OFficer of the Mental, Disease RESEaroh Department-The Secretary, The University, Birmingham (September 1).

University Chair of Chemistry, tenable at the Royal Cancer Hospital-The Academic Registrar, University of London, Richmond College, Richmond, Surrey (September 1).

DHeTiTIAN-The Secretary, University College Hospital, Gower Street, London, W.C.1.

Graduate Assistant Master to teach Chemistry in the Bury Municipal (Evening) Technical College and GENERAL SOIRNCE SUBJECTs in the Bury Junior (Day) Technical School-The Director of Education, Education Offices, Bury.

TEACHER IN ENGINERING-The Principal, County Technical College, Gainsborough, Lincs.

ScIentific Assistant (WOMAN), WITH KNOWLEDGE OF LANGUAGES and UNIVERSity standard QUALifications in Plant Scienct-The Deputy Director, Imperial Forestry Bureau, Oxford.

\section{FORTHCOMING EVENTS}

\author{
Wednesday, August 12
}

INstimuth of Chemistry (LONDON AND South EAstern CoUNTIE SECTION) (at Kodak Hall, Harrow), at 6 p.m.-Dr. J. Grant: "Chemist
versus Forger".

Friday, August 14

ROYaL ARTRONOMOAL Soonsty (at Burlington House, Piccadilly, London, W.1), at 4-30 p.m. -Geophysical Discussion on "The Figure
of the Earth" (to be opened by Sir Gerald Lenox-Conyngham, F.R.S.).

Sunday, August 16

Association of ScIentific Workers (at the Institution of Mechanical Engineers, Storey's Gate, Westminster, London, S.W.1), at 3 p.m.-Conference on "The Scientiflc Film and Scientific Film Societies";

\section{REPORTS and other PUBLICATIONS}

(not included in the monthly Books Supplement)

\section{Great Britain and Ireland}

Report of the Marlborough College Natural History Society for the Year 1941. (No. 90.) Pp. 30. (Marlborough: Marlborough Transactions of the Royal Society of Edinburgh. Vol. 60, Part 2 No. 17: The Genus Primula, Section Nivales. By Sir W. Wright Smith and Dr. H. R. Fletcher. Pp. 563-627. (Edinburgh and London : Oliver and Boyd.) 88 .
[227

Department of Scientific and Industrial Research. Index to the Literature of Food Investigation. Vol. 13, No. 3, December 1941 . Compiled by Agnes Elisabeth Glennie, assisted by Catherine Alexander. Pp. iv +157-232. (London: H.M. Stationery Ofice.; $4 \varepsilon$. 6d. net. [247

\section{Other Countries}

Scientiflc Publications of the Cleveland Museum of Natural History Vol. 8, No. 4: The Infero-Gnathal Plates of Titanichthys. By David
H. Dunkle and Peter A. Bungart. Pp. 49-60. Vol. 8, No. 5: A New Fossil Fish of the Family Leptolepida. By David H. Dunkle History.)

Forest Research Institute, Dehra Dun. Leaflet No. 5: Note on a Hot Air Kiln for Seasoning Half-Wroughts of Shuttles Bobbins Helves, Picker-Arms, etc. By M. A. Rehman. Pp. il +6. Leaflet No. 8: Wooden Poles for Overhead Electric Transmission. By V. D Limaye. Pp. ii +3 . Leaflet No. 11: Types of Timber Seasoning Kilns suitable for Drying Indian Woods. By M. A. Rehman. Pp.
iii +6. (Dehra Dun: Forest Research Institute.) Parliament of the Commonwealth of Australia. Fifteenth Annual Report of the Council for Scientific and Industrial Research for Year
1940-41. Pp. 107. (Canberra: Govern ment Printer.) 48. 9d. [217

Indian Forest Records, New Series. Silviculture, Vol. 4A, No, 2 Provisional Yield Tables for Dalbergia sissoo, Linn. $f$. in the Irrigated Plantations of the Punjab. By Bakhshi Sant Ram. Pp. vi +117 $143+10$ plates. 2.8 rupees; 48 . Utilization, Vol. 2 , No. 4: Third Interim Report on Work under Proj. 8 (Testing of Indian Timbers for Veneers and Plywood). By the Forest Research Institute. Pp. Practical Applications of Recent Lac Research. Edited by $\mathbf{H} . \mathbf{K}$.
Sen. Pp. iv $+78+$ vi +19 plates. (Namkum : Indian Lac Research Sen. Pp. iv $+78+v i+19$ plates. (Namkum: Indian Lac Research
Institute.)
[247

$[247$

Smithsonian Miscellaneous Collections. Vol. 101, No. 17 : Develop mental Physiology of the Grass Seedling, 1 : Inhibition of the Meso cotyl of Avena 8ativa by Continuous Exposure to Light, of Low lication 3685 ) $\mathrm{Pp}$. ii $+10+1$ plate. (Washington, D.C. G lister. (PubPrinting Office.)

Smithsonian Institution. War Background Studies, No. 2: The Evolution of Nations. By John R. Swanton. (Publication 3686.) Pp

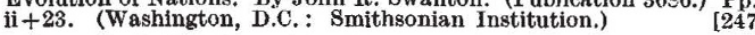

Scientifle Publications of the Cleveland Museum of Natural History. Vol. 5, No. 5: Description of a New House Mouse from Cuba. By Philip N. Moulthrop. Pp. 79-82. (Cleveland, Ohio: Cleveland Museum of Natural History.)
[247

Bulletin of the American Museum of Natural History. Vol. 79, Art. 5: Results of the Vernay-Lang Kalahari Expedition-Large Mammals of Bechuanaland Protectorate. By John Eric Hill. Pp 367-390 + plates 36-43. (New York: American Museum of Natura History.)

\section{Catalogues}

Methyl-Testosterone B.D.H. Pp. 2. Sulphaguanidine B.D.H. Pp. 2 Valogen : Vitamin 'B' and Mineral Tonic. Pp. 2. (London: The British Drug Houses, Ltd.)

Carbon-in-Steel Determination Apparatus : an Improved Ströhlein Type Apparatus for use in Accurate Estimation of Carbon in Stee to 0.01 per cent in about One Minute. (GT. 1332.) Pp. 4. (London: Griftin andTatlock, Itd.) 